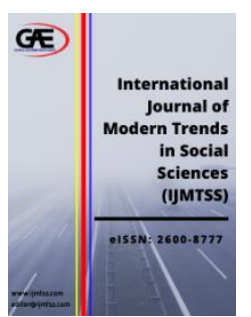

\author{
INTERNATIONAL JOURNAL OF \\ MODERN TRENDS IN \\ SOCIAL SCIENCES \\ (IJMTSS) \\ WWW.ijmtss.com
}

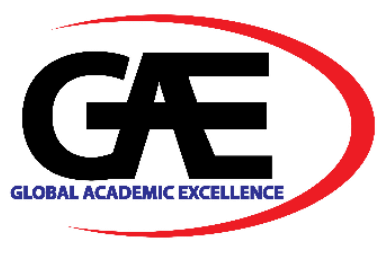

\title{
JOB SATISFACTION INFLUENCE JOB PERFORMANCE AMONG POLYTECHNIC EMPLOYEES
}

\author{
Muhamad Saufiyudin Omar ${ }^{1 *}$, Nurhidayah Rafie ${ }^{2}$, Shahrizal Ahmad Selo ${ }^{3}$
}

1 Department of Tourism \& Hospitality, Politeknik Tuanku Syed Sirajuddin, Pauh Putra, 02600 Arau, Perlis Malaysia.

Email: saufiyudin@yahoo.com

2 Department of Tourism \& Hospitality, Politeknik METrO Kuantan, No. A-5, Jalan Tun Ismail 2, Sri Dagangan 11, 25000 Kuantan, Pahang Malaysia.

Email: nurhidayah@pmku.edu.my

3 Department of Tourism \& Hospitality, Politeknik Merlimau (PMM), Karung Berkumci 1031, Pejabat Pos, 77300

Melaka, Malaysia.

Email: shahrizal@pmm.edu.my

* Corresponding Author

\section{Article Info:}

\section{Article history:}

Received date: 15.10 .2020

Revised date: 21.10 .2020

Accepted date: 01.11.2020

Published date: 03.12.2020

\section{To cite this document:}

Omar, M. S., Rafie, N., \& Selo, S. A. (2020). Job Satisfaction Influence Job Performance among Polytechnic Employees. International Journal of Modern Trends in Social Sciences, 3 (14), 39-46.

DOI: $10.35631 /$ IJMTSS.314003

This work is licensed under CC BY 4.0

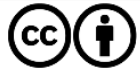

\section{Abstract:}

Job satisfaction is a crucial factor that determines the performance of the employees. However, plenty of researches has been studies on this topic, but very limited studies focus on Polytechnic employees. Therefore, this study aims to examine the influence of job satisfaction and employee performance in the context of Polytechnic employees. The quantitative and cross-sectional method was employed. A total of 130 respondents answered the survey. The simple regression analysis result reveals that job satisfaction significantly and positively influenced employee performance. This suggests that enhancing job satisfaction among Polytechnic employees is critically important to improving their performances. More details about its findings and implications are discussed.

\section{Keywords:}

Employee Performance; Job Satisfaction; Malaysia; Polytechnic Employees

\section{Introduction}

Employee job performance is one common subject in researches. Many companies rely on the employees to survive as well as bring more profit to the company. The employee is a valuable 
asset of the company regardless of the government sector and the private company. They can build and also damage the reputation of the company as well as bring profit (Khan, Abbasi, Waseem, Ayaz, Ijaz, 2016). According to Aktar, Sachu and Ali (2012) and Osunde (2015), employee performance can be influenced by many factors such as company's overall policies, working conditions, training and development of employees, relations between employee and employer, and job satisfaction. One of the ways to enhance employee performance is by enhancing the employees' job satisfaction (Badrianto \& Ekhsan, 2020). Employee job satisfaction is a feeling of a person which comes positively when appraisal comes from person's job (Locke, 1976). It is usually perceived that if the employees are satisfied with their job, their performances will be much better than those employees who are not satisfied with their work (Khan et al., 2016). In other words, if the employees are satisfied with their job, they will make efforts to bring some innovation and creativity by the good performance which will give company important breakthroughs in these changing market conditions (Achieng'Odembo, 2013).

Polytechnic Malaysia is one of the hubs for the nation's human capital development (Jaafar, 2013). Its role has been expended and its establishment has been re-branded in making sure the nation is missions are accomplished by providing the human capital source to the industrial sectors in order to generate the economic growth (Jabatan Pengajian Politeknik, 2009). Furthermore, Polytechnic Malaysia focuses on the skill-based subjects especially related to technical and vocational education and training (TVET) that have been improvised and improved in order to be in line with the national plan in achieving Vision 2020 (Abdullah \& Majid, 2013). Therefore, study on human capital especially the teaching staff is critically important due to high demand and challenges faced by the polytechnic lecturers in teaching the targeted skill to the future nation human.

In this light, Polytechnic employees may gain higher job satisfaction if they are happier with their work. However, most of the employees carry heavy workload, they are not only educating students, but also carry out various management tasks that may lead to dissatisfaction. In addition, the employees also need to multitask, switching between the academic and nonacademic tasks to ensure the organization can run smoothly. As mentioned by Kalleberg (1977) an employee may be satisfied with one or some of the job responsibilities he or she has but dissatisfied with the other tasks in hand. If this dissatisfaction continues, the performance of the employees can be distracted. Hence, study on the influence between employee job satisfaction and employee job performance is important among the polytechnic employees to ensure the operation of the organization runs smoothly.

Many researches have studies on the association between job satisfaction and employee performance globally (Susanj \& Jakopec, 2012; Gupta, 2014; Khan et al., 2016). However, very limited studies that focus on employees performance at polytechnics in Malaysia (Abdullah \& Majid, 2013; Kumar \& Muniandy, 2012). Therefore, the objective of this study is to examine the influence of job satisfaction on employee performance of the Polytechnic employees especially in the Department of Tourism and Hospitality. This study is very important in order to improve employee performance besides to enrich the body of knowledge in that particular area. It can also use be as a guideline for the Head of Department (HoD) and management team to enhance the employee performance especially in the context of Department of Tourism and Hospitality employees. 


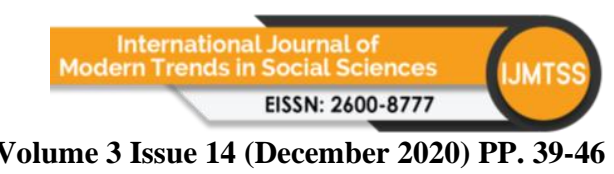

Volume 3 Issue 14 (December 2020) PP. 39-46

\section{Literature Review}

\section{Job Satisfaction}

Job satisfaction is defined as an affective variable that resulted from the evaluation of an individual's work experience (Yuen, Loh, Zhou, \& Wong, 2018). In other words, job satisfaction is the degree or level to which people like their job (Spector, 2008). Job satisfaction can be explained by the theory of equity. According to Adams and Freedman (1976), the equity theory is referring to the balance between an employee's input and output in a workplace. The input are defined as time, loyalty, effort, tolerance, flexibility, enthusiasm, personal sacrifice, skill and trust in superiors. The outputs examples are salary, job security, employee benefits, sense of achievement, praise and reputation. Adams and Freedman (1976) also stated that individuals become demotivated or dissatisfied when the input is not adequately compensated compared to someone doing a comparable job. Therefore, the input and output for the employees must be balanced. In this light, the polytechnic lecturers probably have received adequate output from the employer but, maybe some feel dissatisfied due to high input that is needed to be accomplished. Hence, study on polytechnic lecturer's satisfaction is critically important to help the organizations to understand the importance of having the right people in the right position and also to encourage the organization especially head of the department to increase the level of satisfaction among the employees.

Job satisfaction can come naturally by letting the employee to be self-directed (Shmailan, 2016). Usually, satisfied employees tend to be high-performing and highly committed to the organization. Hence, a successful organization must ensure there is a good relationship between employees and employment (Shmailan, 2016). In addition, unfair assessment by employers in job assignments, promotions, salaries, evaluation reports, etc. compared to other colleagues will adversely affect employee job satisfaction (Torlak \& Kuzey, 2019). Therefore, employers must ensure that all the assessments are evaluated fairly to prevent employees from feeling dissatisfied with the institution. This is because the employees usually evaluate their job either favorable or unfavorable in the organization and whether the job conditions meet his/her expectations or not (Torlak \& Kuzey, 2019).

\section{Job Performance}

Performance is what the organization hires one to do and do well (Campbell, 1990). It is also how efficiently the employee fulfils his/her work-related duties (Torlak, \& Kuzey, 2019). In other words, performance is something that can be achieved by a person or a group of people in an organization in accordance with the authority and responsibility of a person to achieve the goals of the organization in a legitimate way without violating any rules and adhere to morals and ethics (Arifin, 2015). Usually, performing employees will help the leaders to create successful organization (Shmailan, 2016). Therefore, hiring the right person for the right job is a direct link to excellent performance (Edwards, 1991).

A successful organization depends on how high the performances of the employees can meet the objectives of the organization. Therefore, organizations must have strategies to ensure that employees always perform well (Shmailan, 2016). To ensure that employees always perform well, organizations need to understand that employees have their own personal needs and wants that need to be considered in order for them to do their best. This can be seen whether employees feel positively or negatively towards the organization and it needs to be evaluated individually (Schermernorn, 2010). There are several ways to assess employee performance including assessing the ability of employees whether they can achieve the goals and standards Copyright (C) GLOBAL ACADEMIC EXCELLENCE (M) SDN BHD - All rights reserved 


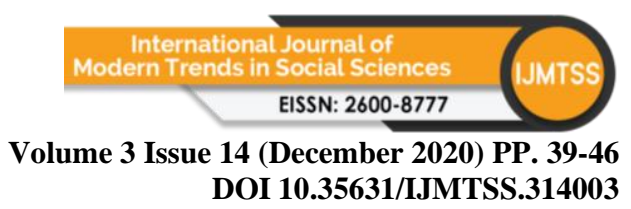

that has been set by the organization (Shmailan, 2016). In addition, performance can be evaluated in terms of quality, quantity, efficiency and effectiveness in performing the tasks given (Arifin, 2015).

\section{Relationship between Job Satisfaction and Employee Performance}

It is important to assess the relationship between job satisfaction and job performance in organizational behavior that ultimately leads to organizational performance (Lannoo \& Verhofstadt, 2016). This is because highly satisfied employees will outperform their dissatisfied colleagues (Yuen et al., 2018). Many scholars stated that satisfied employees tend to be present at work (i.e. low absences), make fewer mistakes (i.e. quality), more productive, and have stronger intentions to stay in the organization (Sánchez-Beaskoetxea \& Coca García, 2015). Based on meta-analysis, it has been reported that the influence of job satisfaction on job performance is generally positive (Christen, Iyer \& Soberman, 2006). According to Velnampy (2008) job satisfaction has positive relation with the employee performance. Shmailan (2016) also states that the relationship of job satisfaction and employee performance is strong. While, $\mathrm{Gu}$ and Chi (2009) also found that a strong relationship between satisfied employee and their performance. Pushpakumari (2008) stated that if the satisfaction level of the employee increases, the level of employee performance will also increase. Therefore, this study formulated that:

Hypothesis 1: Job satisfaction influence employee performance of the Polytechnic employees.

\section{Conceptual Framework}

The independent variable of this study was job satisfaction, while the dependent variable was employee performance. Figure 1 showed the conceptual framework of this study.

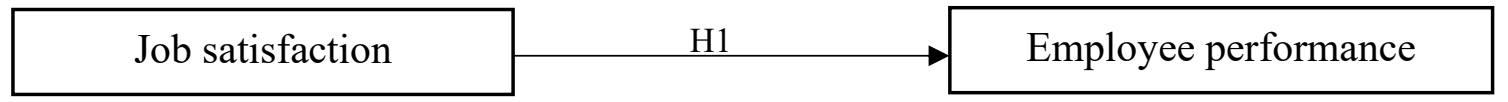

Figure 1: Conceptual Framework

\section{Methodology}

This study employed a quantitative approach with a survey method to collect data. The population of this study comprised of individuals who work at the Department of Tourism and Hospitality at Polytechnic Malaysia as a lecturer. They are government servants and mostly have been in service for more than six years. Stratified random sampling was used to determine the sample by grouping them according to the polytechnic names, namely PTSS, PSIS, PMKu and PMM. Then, all of the sample was randomly selected.

In terms of questionnaire, the study was adapted from previous researchers. The employee job satisfaction was adapted from Brayfield and Rothe (1951), while, employee performance was adapted from Koopmans (2014). In order to make it suitable with the study, some modification was made to the questionnaire. The questionnaire was divided into three parts; Part A: Demographic profile (7 items), Part B: Job satisfaction (18 items) and Part C: Employee performance (18 items). A five-point Likert scale was employed ranging from ' 1 -strongly disagree' to '5-strongly agree' to measure all variables and SPSS was utilized to analyse the data. The questionnaire was originally in English which was then translated into Bahasa Malaysia, and was finally translated once again into English to ensure accuracy. This 
process followed the Brislin (1970) methods. The reliability value for employee job satisfaction and employee performance were 0.901 and 0.886 respectively.

In terms of data collection, the questionnaire started with a letter from the researchers that informs the respondents pertaining to the study objectives and all data gathered will be treated as confidential. In addition, the respondents also be informed that the questionnaire will take approximately 10 minutes to complete. The questionnaires is personally self-administered and the involvement by the respondents are on voluntary basis.

\section{Results}

\section{Respondents Demographic}

Out of 169 samples, only 130 responded on the survey and gave a response rate of $77 \%$. The results reveal that more female employees $(74.6 \%)$ answered the questionnaires compared to male (25.4\%). Mostly, the respondents ageed between $31-40$ years old $(69.2 \%)$ are the highest in answering the questionnaires, followed by $41-50$ years old $(25.4 \%)$ and the lowest were between 51-60 years old (0.8\%). The respondents consist of Malays $(99.2 \%)$ and other race $0.8 \%$. In terms of service, most of the respondents have been in service between 11-15 years (44.6\%), followed by $6-10$ years $(32.3 \%)$ and 15 years and above $(13.8 \%)$. In this study, employees from PTSS (39 employees) and PSIS (39 employees) are the highest respondents, followed by PMM with 36 employees $(27.7 \%)$ and lastly PMKu with 16 employees $(12.3 \%)$. Table 1 provides the demographic profile of the respondents.

Table 1: Demographic Profile of Respondents

\begin{tabular}{llll}
\hline Demographic variables & Category & Frequency & Percentage (\%) \\
\hline Gender & Male & 33 & 25.4 \\
& Female & 97 & 74.6 \\
Age & $21-30$ years old & 6 & 4.6 \\
& $31-40$ years old & 90 & 69.2 \\
& $41-50$ years old & 33 & 25.4 \\
Race & $51-60$ years old & 1 & .8 \\
& Malay & 129 & 99.2 \\
Job Tenure & Others & 1 & .8 \\
& 1-5 years & 12 & 9.2 \\
& 6-10 years & 42 & 32.3 \\
Polytechnic & 11-15 years & 58 & 44.6 \\
& 15 years and above & 18 & 13.8 \\
& PTSS & 39 & 30.0 \\
& PSIS & 39 & 30.0 \\
& PMKu & 16 & 12.3 \\
& PMM & 36 & 27.7 \\
\hline
\end{tabular}

\section{Simple Regression Analysis}

The simple regression analysis was used to analyse the influence of job satisfaction and employee performance. Based on the result in Table 2 indicates that $\mathrm{R}^{2}=0.171$, which means that job satisfaction explains $17.1 \%$ of the variance in the employee performance with $\mathrm{F}=$ $26.479, p=0.000$. The remaining of $82.9 \%$ explained by the other factors. In this case, job satisfaction contributes significantly and positively towards the prediction of employee performance with the beta values of 0.414 . Hence, Hypothesis 1 is supported and showing that Copyright (C) GLOBAL ACADEMIC EXCELLENCE (M) SDN BHD - All rights reserved 
job satisfaction significantly and positively influenced employee performance in the context of Polytechnic employees.

Table 2: Simple Regression Analysis

\begin{tabular}{llllll}
\hline Model & $\mathrm{B}$ & SE B & $\beta$ & $\mathrm{t}$ & Sig. \\
\hline (Constant) & 1.994 & .361 & & 5.528 & .000 \\
Job Satisfaction & .474 & .092 & .414 & 5.146 & .000 \\
\hline
\end{tabular}

Note: $\mathrm{R}^{2}=0.171 \mathrm{p}<0.00$.

\section{Discussion}

The main objective of this study was to examine the influence between job satisfaction and employee performance. Based on the empirical findings gathered, the result indicated that job satisfaction was significantly and positively influenced employee performance. This finding is consistent with previous studies. For instance, Khan et al. (2016) revealed that job satisfaction positively impacted employee performance. Badrianto and Ekhsan (2020) found out that job satisfaction brings a positive and significant effect on employee performance partially and simultaneously meanwhile, Torlak and Kuzey (2019) established that job satisfaction had a significant impact on employee performance.

In this study, there were many aspects that influence the significant and positive relationship between job satisfaction and employee performance. From the finding obtained, most of the employees agreed that their job is interesting than the others job. They also like their job so much and consider the job as pleasant. The employees also agreed that the job that they have right now is better than other jobs elsewhere and feel enjoyment in the job and well satisfied with it. Therefore, keeping employees happy is important for the organization because satisfied employees will be more productive, more loyal, and are less likely to leave their jobs and consequently can positively improve performance (Zhang, Kaiser, Nie \& Sousa-Poza, 2019). Hence, in order to keeps these employee performances at the par, the management, especially Head of Department in the Tourism and Hospitality Department should make sure these elements are fulfilled.

\section{Conclusion and Recommendation}

In sum, this study found that job satisfaction significantly and positively influences employee performance for the Polytechnic employees specifically those in the Department of Tourism and Hospitality context. Moreover, the finding also suggested that the employees of Department of Tourism and Hospitality agreed that their job is more interesting than other jobs and definitely like their job so much. The management especially the Head of Department (HOD) need to encourage their employees and try to keep the job satisfy all the time. Hence, it will help to sustain and improve the performance of the employees all the time.

There were a few limitations in this study that need to be considered. First limitation was the variables used. Since the result of the study showed that there are other factors that influenced employee performance besides job satisfaction, perhaps future studies could include job motivation, job involvement, organization commitment and employee attitudes. Secondly, this study focuses only on employees in the Department of Tourism and Hospitality, perhaps in the future it could include other departments such as Electrical Engineering Department, Mechanical Engineering Department, Department of Information Technology and Communication and Commerce Department. Thirdly, this study focusses on the lecturers only, 
perhaps in the future it could include the employees in the management and non-management as well.

\section{References}

Abdullah, S., \& Majid, F. A. (2013). English language teaching challenges in Malaysia: Polytechnic lecturers' experience. World Applied Sciences Journal, 28(4), 540-547.

Achieng'Odembo, S. (2013). Job satisfaction and employee performance within the Telecommunication Industry in Kenya: A Case of Airtel Kenya Limited. Kenyatta University.

Aktar, S., Sachu, M. K., \& Ali, M. E. (2012). The impact of rewards on employee performance in commercial banks of Bangladesh: an empirical study. IOSR Journal of Business and Management, 6(2), 9-15.

Badrianto, Y., \& Ekhsan, M. (2020). Effect of work environment and job satisfaction on employee performance in Pt. Nesinak Industries. Journal of Business, Management and Accounting, 2(1), 85-91.

Brayfield, A. H., Rothe, H. F. (1951). An index of job satisfaction. Journal of Applied Psychology, 35, 307-311.

Christen, M., Iyer, G., \& Soberman, D. (2006). Job satisfaction, job performance, and effort: A re-examination using Agency Theory. Journal of Marketing, 70(1), 137-150.

Gupta, I. (2014). Impact of job satisfaction on employee's performance. Scholarly Research Journal for Interdisciplinary Studies, 2(15), 2307-2317.

Jaafar, A. K. (2013). Transformasi politeknik fasa dua. Opening Speech at Kolokium Kecermelangan Akademik Pegawai Pendidikan Pengajian Tinggi, Kuala Lumpur.

Jabatan Pengajian Politeknik (2009). Hala tuju transformasi politeknik: Ke arah kelestarian penghasilan modal insan negara. Kementeria Pengajian Tinggi. Putrajaya.

Khan, A. A., Abbasi, S. O. H., Waseem, R. M., Ayaz, M., \& Ijaz, M. (2016). Impact of training and development of employees on employee performance through job satisfaction: A study of telecom sector of Pakistan. Business Management and Strategy 7(1), 29-46.

Koopmans, L. (2014). Measuring individual work performance. Netherlands: Research Center on Physical Activity, Work and Health.

Kumar, J. A ., \& Muniandy, B. (2012). The influence of demographic profiles on emotional intelligence: A study on polytechnic lecturers in Malaysia. International Online Journal of Educational Sciences, 4(1), 62-70.

Lannoo, S., \& Verhofstadt, E. (2016). What drives the drivers? Predicting turnover intentions in the Belgian bus and coach industry. Transportation Research Part A: Policy and Practice, 91, 251-259.

Locke, E. A. (1976). The nature and causes of job satisfaction. Handbook of industrial and organizational psychology, 1, 1297-1343.

Osunde, D. C. (2015). Privatization of public enterprises on Nigeria: Impact on employees' performance and managerial implications. International Journal of Research-Grant Haalayah A Knowledge Repository, 3(3).

Pushpakumari, M. (2008). The impact of job satisfaction on job performance: An empirical analysis. City Forum, 9(1), 89-105.

Sánchez-Beaskoetxea, J., \& García, C. (2015). Media image of seafarers in the Spanish printed press. Maritime Policy Manage, 42(2), 97-110.

Spector, P. E. (2008). Industrial and Organizational Psychology: Research and Practice. Hoboken, New Jersey: John Wiley \& Sons, 
Sušanj, Z., \& Jakopec, A. (2012). Fairness perceptions and job satisfaction as mediators of the relationship between leadership style and organizational commitment. Psihologijske teme, 21(3), 509-526.

Torlak, N. G., \& Kuzey, C. (2019). Leadership, job satisfaction and performance links in private education institutes of Pakistan. International Journal of Productivity and Performance Management, 68(2), 276-295.

Velnampy, T. (2008). Job attitude and employees performance of public sector organizations in Jaffna district, Sri Lanka. GITAM Journal of Management, 6(2), 66-73.

Yuen, K. F., Loh, H. S., Zhou, Q., \& Wong, Y. D. (2018). Determinants of job satisfaction and performance of seafarers. Transportation research part A: policy and practice, 110, 112.

Zhang, X., Kaiser, M., Nie, P., \& Sousa-Poza, A. (2019). Why are Chinese workers so unhappy? A comparative cross-national analysis of job satisfaction, job expectations, and job attributes. PLOS ONE, 14(9), 1-16. 